\title{
Effects of Silver Nanoparticle Exposure on Germination and Early Growth of Pinus sylvestris and Alnus subcordata
}

(Kesan Pendedahan Nanozarah Perak kepada Percambahan dan Pertumbuhan Awal Pinus sylvestris dan Alnus subcordata)

\author{
VILMA BAYRAMZADEH*, MARYAM GHADIRI \& MOHAMMAD HOSSEIN DAVOODI
}

\begin{abstract}
The possible ecological toxicity of silver nanoparticles (AgNP) was evaluated based on germination and growth characteristics of Pinus sylvestris and Alnus subcordata. Seeds were exposed to different concentrations of AgNP in soil (0, 10, 20, 40, 80 and $100 \mathrm{mg} / \mathrm{kg})$ and aqueous suspension (0, 10 and $20 \mathrm{mg} / \mathrm{L})$. Then, seed germination percentage $(G P \%)$, speed of germination (S.G), seedling length (SL), as well as fresh and dry weights (FW and DW) were measured. The results showed that low concentration of AgNP (under $80 \mathrm{mg} / \mathrm{kg}$ ) could be used without detrimental effects on the germination characteristics of $\mathrm{P}$. sylvestris in the soil. Nevertheless, inhibitory effect of AgNP was observed at $10 \mathrm{mg} / \mathrm{L}$ for $\mathrm{P}$. sylvestris in aqueous suspension. The dissimilar results in soil and aqueous suspension were due to the organic matters and clay minerals in the soil. There was no significant difference $(\mathrm{p}<0.01)$ among the treatments of A. subcordata, not only in soil but also in the aqueous suspension.
\end{abstract}

Keywords: Aqueous suspension; inhibitory effect; seed germination; silver nanoparticles; soil; woody plants

\section{ABSTRAK}

Ketoksikan ekologi nanozarah perak (AgNP) dinilai berdasarkan ciri-ciri percambahan dan pertumbuhan Pinus sylvestris dan Alnus subcordata. Benih didedahkan kepada kepekatan berbeza AgNP dalam tanah (0, 10, 20, 40, 80 dan $100 \mathrm{mg} / \mathrm{kg}$ ) dan gantungan akues (0, 10 dan $20 \mathrm{mg} / \mathrm{L})$. Kemudian, peratusan percambahan biji benih (GP\%), kelajuan percambahan (S.G), panjang semaian (SL), serta berat kering dan segar (FW dan DW) diukur. Hasil kajian menunjukkan bahawa kepekatan rendah AgNP (di bawah $80 \mathrm{mg} / \mathrm{kg}$ ) boleh digunakan tanpa kesan-kesan yang memudaratkan terhadap ciri-ciri percambahan P. sylvestris dalam tanah. Walau bagaimanapun, kesan rencatan AgNP diperhatikan pada 10 $\mathrm{mg} / \mathrm{L}$ bagi $\mathrm{P}$. sylvestris pada penggantungan akues. Keputusan yang berbeza dalam tanah dan penggantungan akues adalah disebabkan oleh bahan organik dan mineral tanah liat dalam tanah. Tiada perbezaan yang signifikan ( $<<0.01)$ bagi rawatan A. subcordata, di dalam tanah mahupun di dalam penggantungan akues.

Kata kunci: Kesan rencatan; penggantungan akues; percambahan benih; nanozarah perak; tanah; tumbuhan berkayu

\section{INTRODUCTION}

Nanotechnology is described as the consideration and control of matter at size of 1-100 nm, where unique physical and chemical properties make novel applications achievable (EPA 2007). The special properties, such as high specific area and mobility, could potentially direct to unpredicted health or environmental hazards (Maynard et al. 2006; Wiesner et al. 2006). Many factors have been increasing the importance of the risk determination related to a nanomaterial discharge event, such as its changing properties and condition of scattering (Handy \& Shaw 2007).

One of the substances used in nano-formulation is silver. It is used in a growing number of consumers and medical products. It is utilized just about in all places, and in a wide range to stop the spread of microorganisms. The strong antimicrobial action is the major direction for the development of nanosilver products. About 25\% of the silver production is lost to terrestrial and aquatic ecosystems accidentally or intentionally (approximately $2 / 3$ and 1/3, respectively) (Purcell \& Peters 1998), resulting in toxic effects to organisms. The extensive use of nanosilver has directed to a growing number of research on their toxicity and ecotoxicity.

The greater parts of the toxicity studies on nanomaterial have been focusing on mammals and aquatic species, and relatively few studies have been accomplished using terrestrial species (Christian et al. 2008; EPA 2007; Klaine et al. 2008). The few toxicity studies of nanomaterial on terrestrial species have yielded conflicting results (ElTemsah \& Joner 2010; Jiang et al. 2012; Kumari et al. 2009; Lee et al. 2012; Stampoulis et al. 2009; Yin et al. 2011). For example, Stampoulis et al. (2009) observed that AgNP reduced the biomass and transpiration rates in Cucurbita реро compared to control plants. Similar results were reported for Allium cepa, Lolium multiflorum, ryegrass (Lolium perenne), barley (Hordeum vulgare) and flax (Linum usitatissimum) (El-Temsa \& Joner 2010; Kumari et 
al. 2009; Yin et al. 2011). However, differing result in the growth rate of Phaseolus rabiatus was reported by Lee et al. (2012) while testing in a soil medium. Therefore, there are still many unanswered issues and challenges relating to the effects of AgNP on terrestrial organisms, and mainly woody plants, which may be specifically at risk, due to the large porous in the woody sections.

We studied the effect of AgNP on seed germination and growth characteristics of $A$. subcordata and $P$. sylvestris, since seed germination is the earliest stage in plant growth. Seed germination and seedling elongation are widely used for the phytotoxicity tests due to several advantages like sensitivity, simplicity, low cost, and suitability for reactive chemicals and contaminated soil samples (Lin \& Xing 2007; Munzuroglu \& Geckil 2002; Wang et al. 2001). These two woody species were chosen as they represent both needle- and broad-leaved trees. In addition, plantations with $A$. subcordata and $P$. sylvestris are present in plain areas near the cities in Iran (Gharachorlou et al. 2010; Tabari et al. 2011). Plain areas are polluted with different hazardous materials in varying extents in Iran (Tabari et al. 2008), and yet no results of AgNP toxicity tests on trees of plantation have been reported.

\section{MATERIALS AND METHODS}

\section{PLANT MATERIALS AND EXPERIMENTAL DESIGN}

Seeds of two woody species, $P$. sylvestris and $A$. subcordata, were used in the experiment. The seeds were collected and stored in cool $\left(4^{\circ} \mathrm{C}\right)$ dry condition away from direct light for three months. Seeds were placed in the silty clay and sandy loam textured soil and aqueous suspension in the petri dishes. Seeds were then exposed to the following AgNP concentrations: 0, 10, 20, 40, 80 and $100 \mathrm{mg} \mathrm{AgNP} / \mathrm{kg}$ soil (El-Temsah \& Joner 2010; Kumari et al. 2009; Lee et al. 2012) as well as 0, 10 and $20 \mathrm{mg}$ AgNP per liter of water (El-Temsah \& Joner 2010; Lee et al. 2012; Yin et al. 2011). The experiment was performed in a completely randomized design (RCBD) and each treatment was replicated five times.

\section{NANOSILVER PREPARATION}

Silver nanoparticles (100 nm, 99.5\% metal) were produced using the method described by El-Temsah and Joner (2010). Primary particle diameter was calculated based on Scanning Electron Microscopy and image-processing software (Image J; National Institute of Mental Health) (Figure 1).

\section{SOIL ANALYSIS}

Visually observed silty clay and sandy loam soil were collected from the northern forests of Iran. Soil samples were air dried and ground to enable passage through a 2 $\mathrm{mm}$ sieve. Soil analyses were carried out by the following methods: particle size distribution by the hydrometer method (Gee \& Bauder 1986); organic matter (OM) content

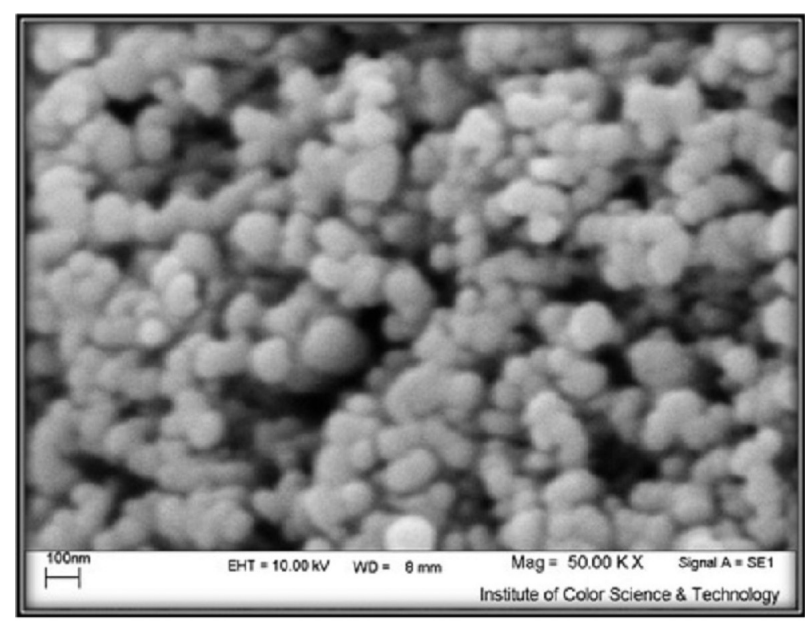

FIGURE 1. Scanning Electron Microscopy image of nanosilver. $\mathrm{Bar}=100 \mathrm{~nm}$

by the Walkley-Black (1934) procedure; $\mathrm{pH}$ values using a glass electrode in mixture of soil and deionized water $(1: 5, w / v)$ and electrical conductivity (EC) of soil samples estimated by Richards (1954). The results of soil analysis are shown in Table 1.

\section{SEED GERMINATION}

Test conditions and germination criteria used were those specified for each species in rules of testing seeds (Association Official Seed Analysts 1970) and international rules for seed testing (International Seed Testing Association 1976). For the seed germination in aqueous suspension, seeds were rinsed with deionized water and then 50 of them were placed in a Petri dish with a disc of filter paper and $5 \mathrm{~mL}$ water or nano-particle suspension with the above-mentioned concentrations per dish (three replicates). Petri dishes were covered and sealed with tape and incubated for 15 days at $22^{\circ} \mathrm{C}$ in a dark growth chamber (MB-60B, USA).

The same plant species and seed densities were used for testing seed germination in the soil. The seeds were placed in Petri dishes and covered with $50 \mathrm{~g}$ of air-dry soil (silty clay and sandy loam). The Petri dishes were subsequently wetted to $75 \%$ of their respective water holding capacities, covered for preventing loss of water and placed in the growth chamber with $16 \mathrm{~h}$ light and 8

TABLE 1. Soil characteristics

\begin{tabular}{lcc}
\hline Soil & Silty clay & Sandy loam \\
\hline $\mathrm{EC}(\mu \mathrm{s} / \mathrm{cm})$ & 0.72 & 0.80 \\
$\mathrm{pH}($ water$)$ & 5.00 & 8.30 \\
Water holding capacity $(\%)$ & 36.50 & 6.90 \\
Organic matter content $(\%)$ & 0.50 & 0.10 \\
Sand $(\%)$ & 12.00 & 76.00 \\
Silt $(\%)$ & 41.00 & 16.00 \\
Clay $(\%)$ & 47.00 & 8.00 \\
\hline
\end{tabular}


h dark cycle at $22^{\circ} \mathrm{C}$ to roughly approximate day length during the spring and early summer in Iran. Loss of water was checked by weighting, and deionized water was added when required. After 15 days, the seed germination and growth were measured.

\section{PARAMETERS}

Germination was counted for $48 \mathrm{~h}$ intervals and continued until no further germination occurred. At the end of the 15 th day, the following parameters were calculated: a) $\quad \begin{aligned} & \text { Seed germination } \\ & \text { percentage }(\mathrm{GP} \%)\end{aligned}=\frac{\text { germinated seeds }}{\text { total seeds }} \times 100$

b) Speed of germination (SG) was calculated based on the following formula of Maguire (1962)

$S . G .=\frac{X 1}{Y 1}+\frac{X 2-X 1}{Y 2}+\ldots . . \frac{X n-X n-1}{Y n}$

where; X1, X2 and Xn are numbers of seeds germinated on $1^{\text {st }}, 2^{\text {nd }}$, and $\mathrm{n}^{\text {th }}$ day, respectively. $\mathrm{Y} 1$, Y2 and Yn are numbers of days from sowing to $1^{\text {st }}$, $2^{\text {nd }}$ and $\mathrm{n}^{\text {th }}$ count.

c) Seedling length (SL) in millimeter (mm)

d) Fresh weight (FW) in gram (g)

e) Dry weight (DW, in g): seedlings were placed in a paper cover, dried in the oven at $85 \pm 2^{\circ} \mathrm{C}$ for $48 \mathrm{~h}$ and were weighed to obtain the dry weight

\section{STATISTICAL ANALYSIS}

The data were analyzed by Statgraphics Plus Professional 16.0.3 software (Bayramzadeh et al. 2008; Roschewitz et al. 2005). The comparison of means was done using Fisher's Least Significant Difference (LSD) Test $(p<0.01)$ for aqueous suspension and Tukey's Honestly Significant Differences (HSD) for soil environment $(p<0.01)$. Spearman's rank order correlation coefficient was used to test the relationship between the studied growth and germination characteristics and different concentrations of AgNP.

\section{RESULTS}

The AgNP affected seed germination and growth characteristics in a different way for the two woody plants. These species showed dissimilar responses to AgNP due to their anatomical (e.g. types of cell) and morphological (e.g. leaf form) differences. Therefore, we did not compare them with each other statistically, and our objective was to evaluate the responses of each species unconnectedly.

SOIL

AgNP had significant inhibitory effects $(p<0.01)$ on $P$. sylvestris in silty clay and sandy loam textured soils.
The increasing concentrations of AgNP had decreased the characteristics SG\%, SG, SL, FW and DW significantly (Figures $2 \& 5$; Table 2). The reduction of the characteristics was noticeable in 80 to $100 \mathrm{mg} / \mathrm{kg}$ in both soil textures. It is interesting to note that the studied parameters in the silty clay soil (even in control) were less than those in the sandy loam soils (Figures $5 \& 6$ ). The results also showed that there was no significant difference among the treatments of $A$. sabcordata $(p<0.01)$ in both silty clay and sandy loam textured soils (Figure 3; Table 2). However, $A$. sabcordata showed better growth in silty clay than sandy loam textured soil.

\section{AQUEOUS SUSPENSION}

Significant $(p<0.01)$ negative effects on germination and growth characteristics of $P$. sylvestris was observed in the aqueous suspension (Figure 4). The significant reductions in $\mathrm{GP} \%$, SG, SL, FW and DW was started from $10 \mathrm{mg}$ AgNP/L water (Figure 4). Different concentrations of AgNP in aqueous suspension had no significant $(p<0.01)$ effects on the germination and growth characteristics of A. sabcordata (Figure 4).

\section{DISCUSSION}

In this study, we investigated the effect of AgNP on germination and growth of $A$. subcordata and $P$. sylvestris in soil and aqueous suspension since few results of toxicity tests with trees have been reported (Seeger et al. 2009). The results showed that AgNP had significant negative effects $(p<0.01)$ on germination and growth characteristics of $P$. sylvestris in both soil textures (silty clay and sandy loam) and aqueous suspension.

The seed germination and growth characteristics of P. sylvestris reduced while the concentration of AgNP increased. The noticeable reduction was observed at 80 $\mathrm{mg} \mathrm{AgNP} / \mathrm{kg}$ soil and $10 \mathrm{mg} \mathrm{AgNP} / \mathrm{L}$ of water. It should be mentioned that AgNP did not impeded the germination completely. This finding is in agreement with those reported for ryegrass, barley, and flax (El-Temsah \& Joner 2010). The $\mathrm{SG} \%$, SG, SL, FW and DW in the all treatments of the silty clay soil (even in control) were less than sandy loam soils (Figures 2, $5 \& 6$ ). These results can be due to the fact that $P$. sylvestris grows well on different soils but optimum growth is on the freely drained sands and gravels (Steven \& Carlisle 1959).

The inhibitory effects of AgNP on the studied characteristics of the $P$. sylvestris were observed at very low concentration in aquatic suspension $(10 \mathrm{mg} / \mathrm{L})$ when compared to the soil $(80 \mathrm{mg} / \mathrm{kg})$. This can be due to the fact that nano-particles are likely to react with constituents of environmental matrices like soil and water (Brant et al. 2007). In addition, organic matters and clay minerals in the soil are known to decrease bioavailability and phytotoxicity of both inorganic (Lombi et al. 2002) and organic pollutants (Roberts et al. 2007). 

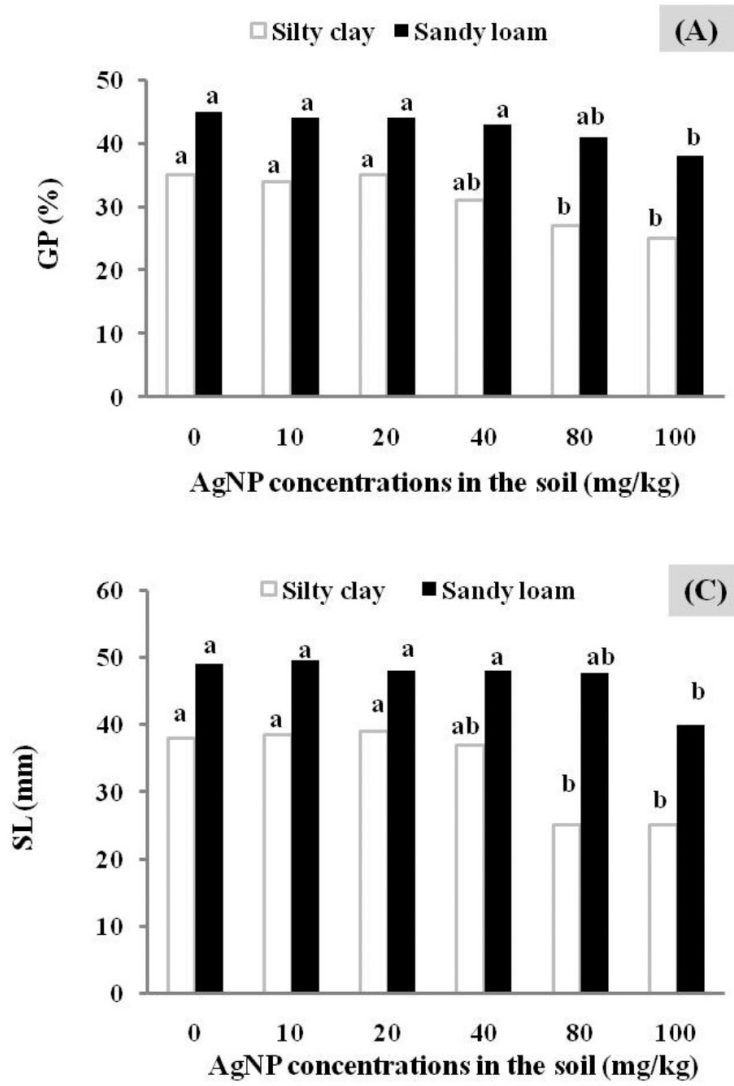
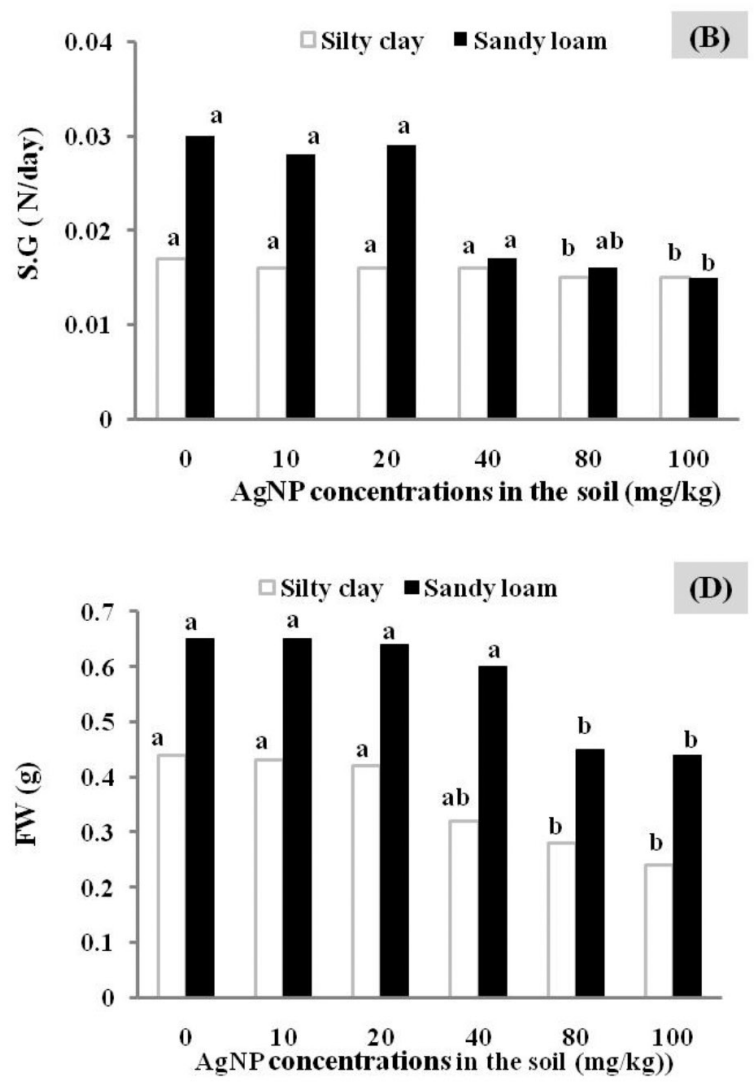

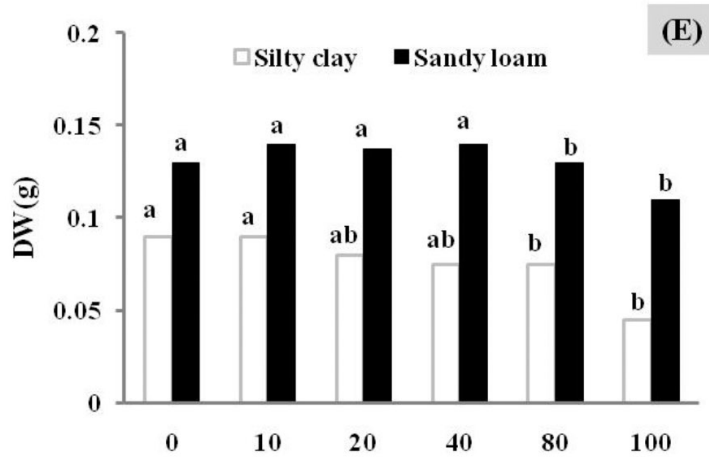

AgNP concentrations in the soil $(\mathrm{mg} / \mathrm{kg})$

FIGURE 2. Seed germination percentage (GP\%, A), speed of seed germination (SG, B), seedling length (SL, C), fresh weight (FW, D) and day weight (DW, E) of P. sylvestris in the soil. $n=5$. Bars show S.D. means with the same letters are not significantly different at $P<0.01$ by Tukey's HSD procedure

TABLE 2. Correlation analysis (Spearman Rank Order Correlations) between the growth and germination characteristics of $P$. sylvestris and A. subcordata with AgNP concentrations in the soil and aqueous suspension

\begin{tabular}{|c|c|c|c|c|c|c|c|}
\hline \multirow[t]{3}{*}{ Woody species } & \multicolumn{2}{|c|}{ Environmental media } & \multicolumn{5}{|c|}{ Correlation coefficient } \\
\hline & & & \multicolumn{5}{|c|}{ Growth and germination characteristics } \\
\hline & & & $\mathrm{GP} \%$ & SG & SL & FW & DW \\
\hline \multirow{3}{*}{ P. sylvestris } & \multirow{2}{*}{ Soil } & Silty clay & $-0.87 * *$ & $-0.57 *$ & $-0.75 * *$ & $-0.95 * *$ & $-0.83^{* *}$ \\
\hline & & Sandy loam & $-0.91 * *$ & $-0.86 * *$ & $-0.89 * *$ & $-0.90 * *$ & $-0.47 *$ \\
\hline & \multicolumn{2}{|l|}{ Aqueous suspension } & $-0.94 * *$ & $-0.71 *$ & $0.94 * *$ & $0.95 * *$ & $0.95 * *$ \\
\hline \multirow{3}{*}{ A. subcordata } & \multirow{2}{*}{ Soil } & Silty clay & 0.50 & 0.23 & -0.32 & -16 & -0.23 \\
\hline & & Sandy loam & -0.22 & -0.16 & -0.19 & 0.17 & -0.19 \\
\hline & \multicolumn{2}{|l|}{ Aqueous suspension } & -0.59 & -0.20 & 0.01 & 0.32 & -0.43 \\
\hline
\end{tabular}

GP\% (Seed germination percentage), S.G (speed of seed germination), SL (seedling length), FW (fresh weight) and DW (day weight); ** Significant at $p<0.01 ; *$ Significant at $p<0.05$ 

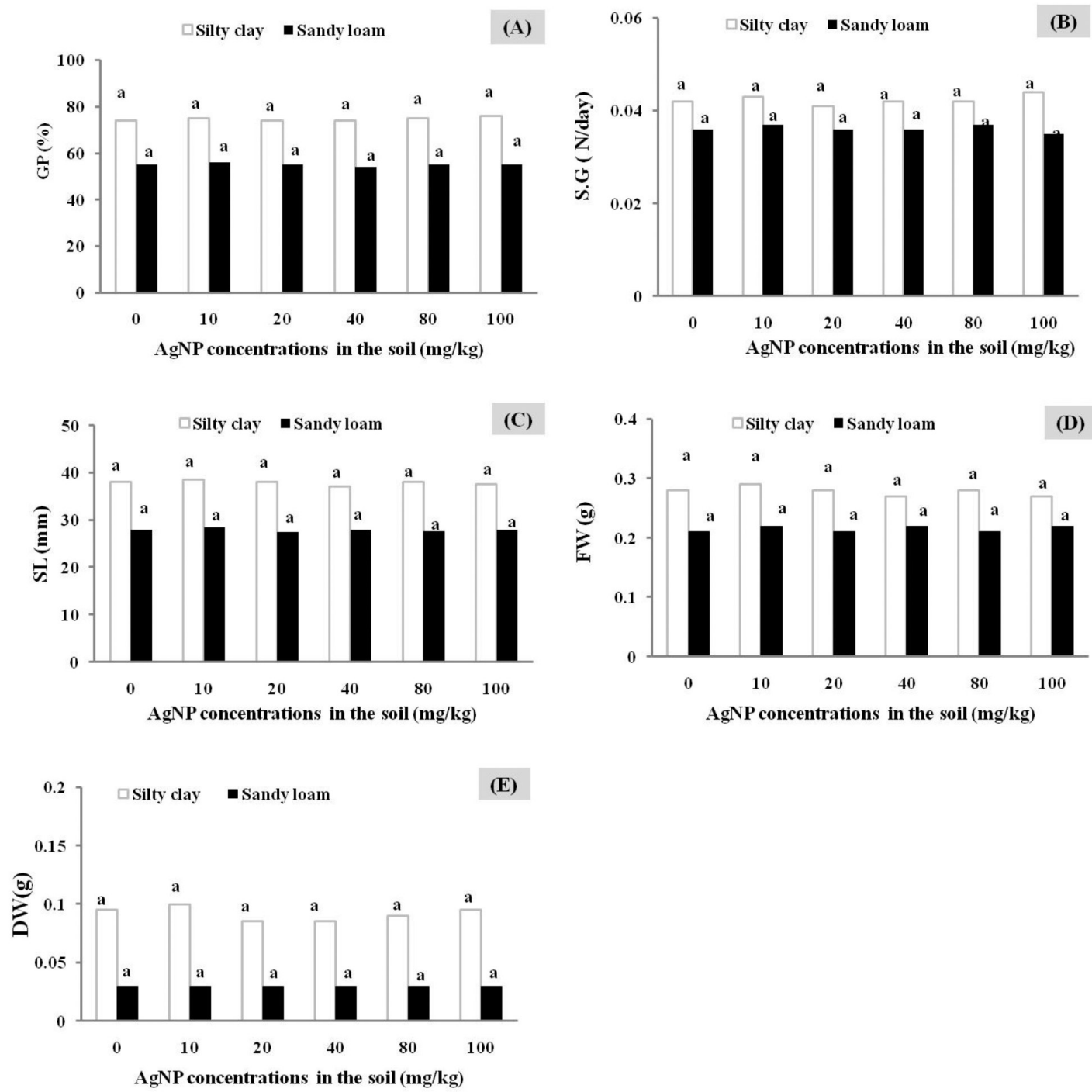

FIGURE 3. Seed germination percentage (GP\%, A), speed of seed germination (SG, B), seedling length (SL, C), fresh weight (FW, D) and day weight (DW, E) of A. subcordata in the soil $(. n=5$. Bars show S.D. means with the same letters are not significantly different at $p<0.01$ by Tukey's HSD procedure

The phytotoxicity profile of AgNP has been frequently investigated via seed germination and growth characteristics for annual plants (El-Temsah \& Joner 2010; Jiang et al. 2012; Lee et al. 2012). The findings for the annual plants reported by El-Temsa and Jiang (2012), Jiang et al. (2012), Kumari et al. (2009), Lee et al. (2012), Stampoulis et al. (2009) and Yin et al. (2011), were very similar to our findings for $P$. sylvestris. The toxicities of the AgNP in the P. sylvestris and other annual plants are likely to be attributed to three mechanisms: Generation of reactive oxygen species (ROS) (Navarro et al. 2008), which can damage the cell membrane; Penetration of nanoparticles into the cell where they interfere with intracellular metabolism (a nano-Trojan-horse type mechanism) (Limbach et al. 2007; Luoma 2008); and Release of metal ions that hinder enzyme functions (Hwang et al. 2007).

The results for A. subcordata completely differed from those obtained for P. sylvestris. The lack of restrictive impact can be likely due to the paucity of the absorbance or resistance of A. subcordata against the AgNP. The results of $A$. subcordata is comparable to the findings of Seeger et al. (2009) who studied the toxicity of $\mathrm{TiO}_{2}$ nanoparticle on willow trees and came to the conclusion that willow trees are not in particular vulnerable to nanosized $\mathrm{TiO} 2$-particles.

We conclude that in contrast to P. sylvestris, $A$. subcordata is not sensitive to nanosized silver particles in the conditions, concentrations, and time periods used in this study. However, the preliminary outcomes of this study should be verified by other types of nanoparticles, its concentrations, duration, and other tree species.

\section{ACKNOWLEDGEMENTS}

This work was funded by Karaj Branch Islamic Azad University. Authors are thankful to the director of Key Laboratory of Alpine Ecology and Biodiversity, Institute of Tibetan Plateau Research, Chinese Academy of Sciences for providing laboratory and necessary facilities. 


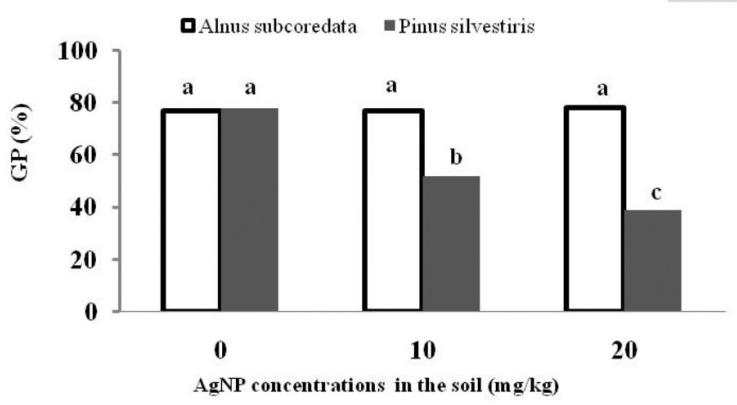

(C)

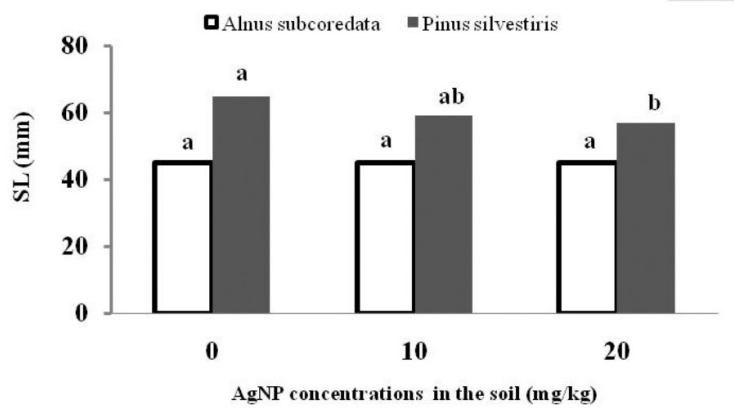

(E)

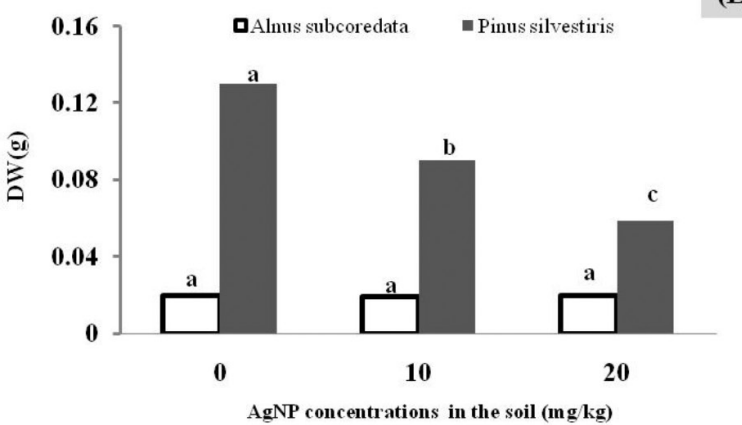

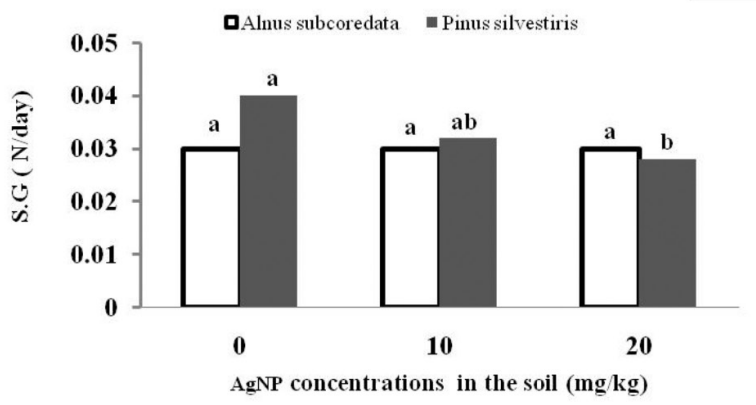

(D)

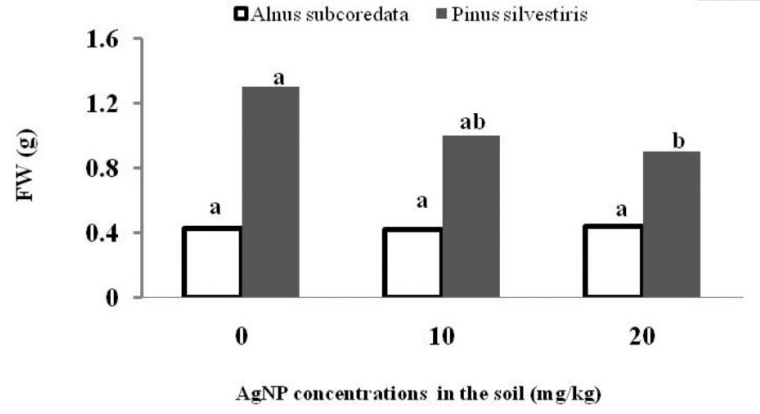

FIGURE 4. Seed germination percentage (GP\%, A), speed of seed germination (SG, B), seedling length (SL, C), fresh weight (FW, D) and day weight (DW, E) of P. sylvestris and A. subcordata in the water. $n=5$. Bars show S.D. means with the same letters are not significantly different at $p<0.01$ by Fisher's LSD procedure

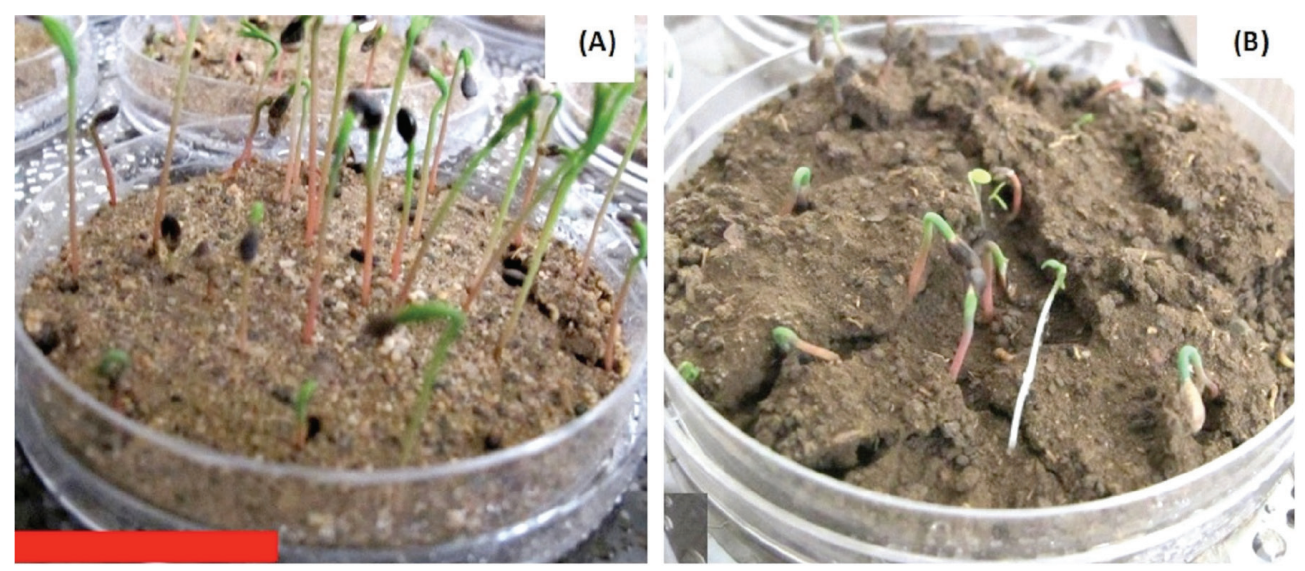

FIGURE 5. Seed germination of P. sylvestris in $0 \mathrm{mg} / \mathrm{Kg}$ (A) and $80 \mathrm{mg} / \mathrm{Kg}$ (B) of AgNP in sandy loam soil. Scale bar $=50 \mathrm{~mm}$ 

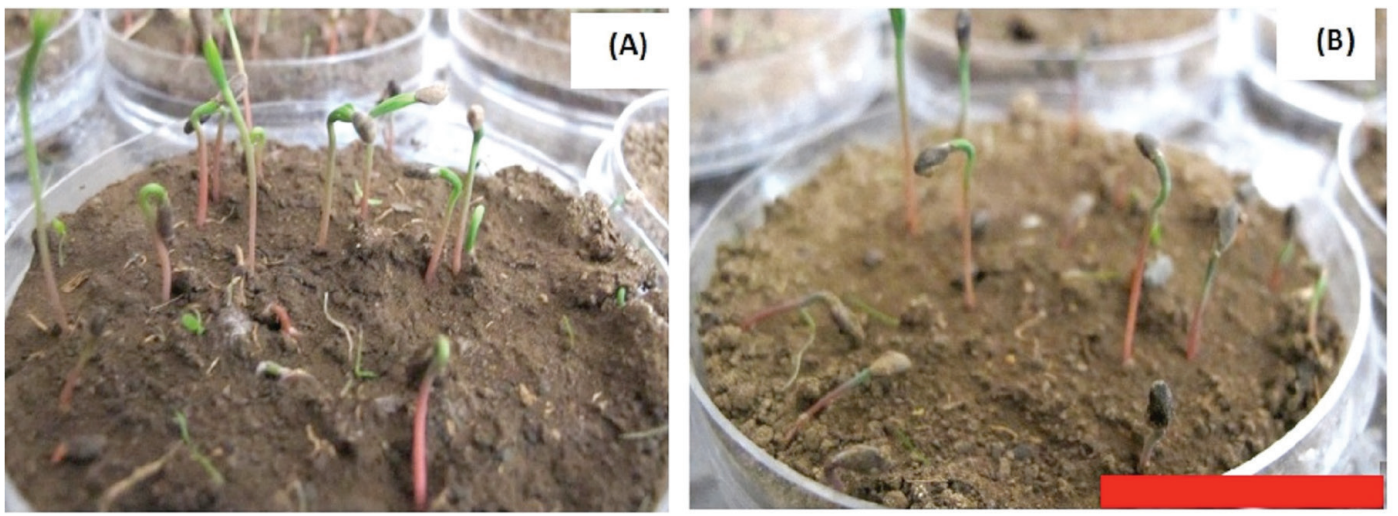

FIGURE 6. Seed germination of P. sylvestris in $0 \mathrm{mg} / \mathrm{Kg}$ (A) and $80 \mathrm{mg} / \mathrm{Kg}$ (B) of AgNP in silty clay soil. Scale bar $=50 \mathrm{~mm}$

\section{REFERENCES}

Association of Official Seed Analysts. 1970. Rules for testing seed. Association Seed Analysts 60: 1-116.

Bayramzadeh, V., Funada, R. \& Kubo, T. 2008. Relationships between vessel element anatomy and physiological as well as morphological traits of leaves in Fagus crenata seedlings originating from different provenances. Trees 22(2): 217-224.

Brant, J.A., Labille, J., Bottero, J.Y. \& Wiesner, M.R. 2007. Nanoparticle transport, aggregation and deposition. In Environmental Nanotechnology, Applications and Impacts of Nanomaterials, edited by Wiesner, M.R. \& Bottero, J.Y. New York: McGraw. pp. 231-294.

Christian, P., von der Kammer, F., Baalousha, M. \& Hofmann, T.H. 2008. Nanoparticles structure, properties, preparation and behavior in environmental media. Ecotoxicology 17(5): 326-343.

El-Temsah, Y.S. \& Joner, E. 2010. Impact of Fe and Ag nanoparticles on seed germination and differences in bioavailability during exposure in aqueous suspension and soil. Environmental Toxicology 27(1): 42-49.

EPA. 2007. Nanotechnology White Paper. Washington: U.S. Environmental protection agency report EPA 100/B-07/001.

Gee, G.W. \& Bauder, J.W. 1986. Particle size analysis. In Methods of Soil Analysis, edited by Klute, A. Wisconsin: Soil Science Society of America, Madison. pp. 383-411.

Gharachorlou, A., Kiadalivi, H., Adeli, E. \& Alijanpoor, A. 2010. Studying quantity and quality of coniferous species in Arasbaran Forests (Case study: Heresar and Kalaleh Regions). World Applied Sciences Journal 8: 334-338.

Handy, R.D. \& Shaw, B.J. 2007. Toxic effects of nanoparticles and nanomaterials: Implications for public health, risk assessment and the public perception of nanotechnology. Health, Risk and Society 9(2): 125-144.

Hwang, M.G., Katayama, H. \& Ohgaki, S. 2007. Inactivation of Legionella pneumophila and Pseudomonas aeruginosa: Evaluation of the bactericidal ability of silver actions. Water Research 41(18): 4097-4104.

International Seed Testing Association. 1976. International rules for seed testing 1976. Seed Science and Technology 4: 1-177.

Jiang, H., Li, M., Chang, F., Li, W. \& Yin, L. 2012. Physiological analysis of silver nanoparticles and $\mathrm{AgNO} 3$ toxicity to Spirodela polyrrhiza. Environmental Toxicology and Chemistry 31(8): 1880-1996.

Klaine, S.J., Alvarez, P.J., Batley, G.E., Fernandes, T.F., Handy, R.D., Lyon, D.Y., Mahendra, S., McLaughlin, M.J. \& Lead,
J.R. 2008. Nanomaterials in the environment: Behaviour, fate, bioavailability and effects. Environmental Toxicology and Chemistry 27(9): 1825-1851.

Kumari, M., Mukherjee, A. \& Chandrasekaran, N. 2009. Genotoxicity of silver nanoparticle in Allium cepa. Science of the Total Environment 407(19): 5243-5246.

Lee, W.M., Kwak, J.I. \& An, Y.J. 2012. Effect of silver nanoparticles in crop plants Phaseolus radiates and Sorghum bicolour: Media effect on phytotoxicity. Chemosphere 86(5): 491-499.

Limbach, L.K., Wick, P., Manser, P., Grass, R.N., Bruinink, A. \& Stark, W.J. 2007. Exposure of engineered nanoparticles to human lung epithelial cells: Influence of chemical composition and catalytic activity on oxidative stress Environmental Science and Technology 41(11): 4158-4163.

Lin, D. \& Xing, B. 2007. Phytotoxicity of nanoparticles: Inhibition of seed germination and root growth. Environmental Pollution 150(2): 243-250.

Lombi, E., Zhao, F.J., Zhan, G., Sun, B., Fitz, W., Zhang, H. \& McGrath, S.P. 2002. In situ fixation of metals in soils using bauxite residue: Chemical assessment. Environmental Pollution 118(3): 435-443.

Luoma, N.S. 2008. Silver nanotechnologies and the environment: Old problems or new challenges? Woodrow Wilson International Centre for Scholars: Scholars Project on Emerging Nanotechnologies, Washington, DC. p. 26.

Maguire, J.O. 1962. Speed of germination-aid in selection and evaluation for seedling emergence and vigour. Crop Science 2(1): 176-177.

Maynard, A.D., Aitken, R.J., Butz, T., Colvin, V., Donaldson, K., Oberdörster, G., Philbert, M. A., Ryan, J., Seaton, A., Stone, V., Tinkle, S.S., Tran, L., Walker, N.J. \& Warheit, D.B. 2006. Safe handling of nano technology. Nature 444(7117): 267-269.

Munzuroglu, O. \& Geckil, H. 2002. Effects of metals on seed germination, root elongation, and coleoptile and hypocotyl growth in Triticum aestivum and Cucumis sativus. Arch Environmental Contamination and Toxicology 43(2): 203213.

Navarro, E., Boun, A., Behra, R., Hartmann, N.B., Filser, J., Mioo, A.O., Quigg, A., Santschi, P.H. \& Sigg, L. 2008. Environmental behaviour and ecotoxicity of engineered nanoparticles on algae, plants and fungi. Ecotoxicology 17(5): 372-386 
Purcell, T.W. \& Peter, J.J. 1998. Sources of silver in the environmental. Environmental Toxicology and Chemistry 17(4): 539-546.

Roberts, A.P., Mount, A.S., Seda, B., Souther, J., Qiao, R., Lin, S., Ke, P.C., Rao, A.M. \& Klaines, J. 2007. In vivo biomodification of lipid-coated carbon nano-tubes by Daphnia magna. Environmental Science and Technology 41(8): 3025-3029.

Richards, L.A. 1954. Diagnosis and improvement of saline and alkali soils. Agronomy Journal 60: 65-86.

Roschewitz, I., Gabriel, D., Tscharntke, T. \& Thies, C. 2005. The effects of landscape complexity on arable weed diversity in organic and conventional farming. Journal of Applied Ecology 42(5): 873-882.

Seeger, E., Baun, A., Kastner, M. \& Trapp, S. 2009. Insignificant acute toxicity of $\mathrm{TiO}_{2}$ nanoparticles to willow trees. Journal of Soils and Sediments 9(1): 46-53.

Stampoulis, D., Sinha, S.K. \& White, J.C. 2009. Assay-dependent phytotoxicity of nanoparticles to plant. Environmental Science and Technology 43(24): 9473-9479.

Steven, H.M. \& Carlisle, A. 1959. The Native Pinewoods of Scotland. Edinburgh: Oliver and Boyd Publications. p. 368

Tabari, M., Salehi, A. \& Ali-Arab, A.R. 2008. Effects of waste water application on heavy metals ( $\mathrm{Mn}, \mathrm{Fe}, \mathrm{Cr}$ and $\mathrm{Cd}$ ) contamination in a black locust stand in semi-arid zone of Iran. Research Journal of Environmental Sciences 7(4): 382-388.

Tabari, M., Rostamabadi, A. \& Salehi, A. 2011. Comparison of plant diversity and stand characteristics in Alnus subcordata C.A. Mey and Taxodium distichum (L.) L.C. Rich. Ecologia Balkanica 3(2): 15-24.

Walkley, A.\& Black, I.E. 1934. An examination of the degtjareff method for three determining soil organic mother and a proposed modification of the chromic acid titration method. Soil Science 37(1): 29-38.

Wang, X.D., Sun, C., Gao, S.X., Wang, L.S. \& Han, S.K. 2001. Validation of germination rate and root elongation as indicator to assess phytotoxicity with Cucumis sativus. Chemosphere 44(8): 1711-1721.
Wiesner, M.R.,Lowry, G.V.,Alvarez,P., Dionysiou, D.\& Biswas, P. 2006. Assessing the risks of manufactured nanomaterials. Environmental Science and Technology 40(14): 4336-4345.

Yin, L., Cheng, Y., Espinasse, B., Colman, B.P., Auffan, M. \& Wiesner, M. 2011. More than the ions: The effects of silver nanoparticles on Lolium multiflorum. Environmental Science and Technology 45(6): 2360-2367.

Vilma Bayramzadeh*

Department of Wood Sciences

Faculty of Agricultural Sciences and Natural Resources

Karaj Branch, Islamic Azad University, Karaj

Iran

\section{Maryam Ghadiri}

M.Sc. Department of Soil Sciences

Faculty of Agricultural Sciences and Natural Resources Karaj Branch, Islamic Azad University, Karaj

Iran

Mohammad Hossein Davoodi

Soil and Water Research Institute, Karaj

Iran

*Corresponding author; email: vbayramzadeh@gmail.com

Received: 9 June 2018

Accepted: 12 March 2019 